\title{
FERTILIZER PHOSPHORUS IN VARIOUS FRACTIONS OF SOIL PHOSPHORUS
}

\author{
ARMi KaILA \\ University of Helsinki, Department of Agricultural Chemistry
}

Received March 25, 1963

The effectiveness of fertilizer phosphorus mainly depends on the nature and the rate of its reactions in soils. Usually, the availability of the water-soluble phosphates rapidly decreases as their phosphorus is sorbed by the soil constituents, or as it turns over to some less soluble forms. On the other hand, a poor solubility will limit the uptake by plants of the phosphorus in some other fertilizers, and only by the activity of microorganisms or non-biological factors a more or less slow mobilization of their phosphorus may be carried out.

The reactions of monocalcium phosphate and dicalcium phosphate in soil have been studied in numerous investigations [e.g. 2, 15, 17 and the large research work in the branches of TVA reviewed by HufFMAN (9)]. The dissolved monocalcium phosphate appears to be fairly rapidly precipitated as dicalcium phosphate or sorbed by iron and aluminium oxides and hydroxides. Dicalcium phosphate seems to stay for a longer time in the soil without marked changes. Less work has been done on the chemistry of rock phosphates in the soil $(4,5,7,14,16)$. It is likely that the hydroxyapatite is only slowly dissolved in most soils, and that a large part of it may be stored even for decades in the soil as almost unchanged apatite grains. The chemical reactions of the phosphorus compounds of basic slag in soils seem to be rather unknown.

In some previous works the writer $(10,11)$ tried to follow the fate of superphosphate phosphorus and hyperphosphate phosphorus in soils of field trials by comparing the amounts of phosphorus in a given fraction present in the fertilized soil and the amount of phosphorus in the same fraction present in the unfertilized soil. The fractionation method of CHANG and JACKson (3) was employed. It was found that in all the more or less acid mineral soils studied, a treatment with superphosphate tended to increase the fractions which were extracted by $\mathrm{NH}_{4} \mathrm{~F}$ and $\mathrm{NaOH}$. During a longer period of dressing with superphosphate a marked increase in the organic phosphorus content of a peat soil could be detected. The effect of 
hyperphosphate phosphorus was mainly found in the acid-soluble fraction, but also in the ammonium fluoride soluble fraction somewhat higher values for the fertilized soils were obtained.

In the present paper the same method is used for studying under laboratory conditions the nature of reaction products, with various kinds of soils, of superphosphate, dicalciumphosphate, hyperphosphate, basic slag, and a Finnish phosphate preparate.

\section{Material and methods}

Four soil samples were selected for the present study. They were a sandy clay C 7, a silt soil C 3 , and two clay loams Vi 1 and Vi 3 which represent typical Litorina clays. The samples C $7, \mathrm{C} 3$ and Vi 3 were taken from the plough layer, the sample Vi 1 from the depth of 20 to $40 \mathrm{~cm}$; all the samples were from cultivated soils. The soils are characterized by the values listed in Table 1.

Table 1. Soil samples

\begin{tabular}{|c|c|c|c|c|c|c|c|c|c|c|}
\hline \multirow{2}{*}{$\begin{array}{c}\text { Number } \\
\text { of } \\
\text { sample }\end{array}$} & \multirow{2}{*}{$\mathrm{pH}$} & \multirow{2}{*}{$\begin{array}{c}\text { Ogr. C. } \\
\%\end{array}$} & \multirow{2}{*}{$\begin{array}{c}\text { Clay } \\
\%\end{array}$} & \multirow{2}{*}{$\begin{array}{c}\mathrm{Al} \\
\mathrm{ppm}\end{array}$} & \multirow{2}{*}{$\begin{array}{c}\mathrm{Fe} \\
\mathrm{ppm}\end{array}$} & \multirow{2}{*}{$\mathbf{k}$} & \multicolumn{4}{|c|}{ Inorg. P ppm, extracted by } \\
\hline & & & & & & & $\mathrm{NH}_{4} \mathrm{Cl}$ & $\mathrm{NH}_{4} \mathrm{~F}$ & $\mathrm{NaOH}$ & $\mathrm{H}_{2} \mathrm{SO}_{4}$ \\
\hline C 7 & 6.0 & 3.6 & 47 & 2260 & 4740 & 135 & 4 & 63 & 192 & 444 \\
\hline C 3 & 4.5 & 4.2 & 28 & 2710 & 5020 & 324 & 3 & 107 & 207 & 231 \\
\hline Vi 3 & 4.4 & 4.6 & 47 & 7420 & 22080 & 1000 & 0 & 22 & 319 & 107 \\
\hline Vi 1 & 3.7 & 2.1 & 54 & 5090 & 12880 & 860 & 0 & 26 & 312 & 143 \\
\hline
\end{tabular}

The $\mathrm{pH}$-values determined in $0.02 \mathrm{~N} \mathrm{CaCl}_{2}$-suspension in the ratio of 1 to 2.5, show that the samples $\mathrm{C} 3, \mathrm{Vi} 3$, and $\mathrm{Vi} 1$ are distinctly acid and the sample C 7 only slightly acid. The content of organic carbon is fairly high in all the samples, even in the sample Vi 1 from the deeper layer. The samples are relatively rich in clay; also in the silt sample C 3 , the content is close to the limit of clay soils.

The contents of aluminium and iron extracted by Tamm's acid ammonium oxalate are almost equal in the samples C 7 and C 3 , while the values for the Litorina soils, particularly for the sample $\mathrm{Vi} 3$, are markedly higher. The abundance of aluminium and iron in these latter soils probably accounts for the high values of $k$ which is an indicator of the phosphate sorption capacity of the soil (12). This indicator is low in the slightly acid sample C 7 , and in sample C 3 it corresponds to the typical mean value in mineral soils (12).

Fractions of inorganic phosphorus were determined by the procedure of CHANG and JACKSON (3); instead of neutral $\mathrm{NH}_{4} \mathrm{~F}$, the slightly alkaline extractant recommended by FIFE (6) was used. The results show a high content of alkali-soluble phosphorus in the Litorina soils, but also in the other soils this fraction is marked. The fraction dissolved by ammonium fluoride is rather low in the Litorina soils, and in all the soils lower than the acid-soluble fraction. The latter is highest in the soil with the highest $\mathrm{pH}$, but also in the rather acid sample $\mathrm{C} 3$, this fraction tends to 
contain the largest part of phosphorus extracted. The easily soluble phosphorus, or phosphorus extracted by ammonium chloride, is low in all the samples.

The fertilizers studied in the present work are listed in Table 2. The dicalcium phosphate dihydrate is a pure chemical. The "Finnish phosphaten is a preparate of fused apatite obtained from Lohjan Kalkkitehdas Oy. for laboratory studies.

Table 2. Fractions of fertilizer phosphorus

\begin{tabular}{|c|c|c|c|c|c|}
\hline & \multirow{2}{*}{$\begin{array}{c}\text { Total } \\
\% \\
\%\end{array}$} & \multicolumn{4}{|c|}{ Per cent of total $\mathrm{P}$ extracted by } \\
\hline & & $\mathrm{NH}_{4} \mathrm{Cl}$ & $\mathrm{NH}_{4} \mathrm{~F}$ & $\mathrm{NaOH}$ & $\mathrm{H}_{2} \mathrm{SO}_{4}$ \\
\hline Superphosphate & 8.9 & 94 & 1 & 0 & 5 \\
\hline $\mathrm{CaHPO}_{4} \cdot 2 \mathrm{H}_{2} \mathrm{O}$ & 18.0 & 10 & 67 & 0 & 23 \\
\hline Hyperphosphate & 12.8 & 0 & 3 & 0 & 97 \\
\hline Basic slag & 6.2 & 2 & 1 & 0 & 77 \\
\hline "Finnish phosphate" & 7.8 & 4 & 7 & 0 & 89 \\
\hline
\end{tabular}

The fractionation method was applied to these fertilizers, and the results obtained when the ratio of extraction was 1 to 100 , are reported in Table 2 . If a lower ratio would have been used, probably a larger part had been dissolved by the first treatments, while in a higher ratio, somewhat less of the fertilizer phosphorus was found in the first fractions.

The distribution of superphosphate phosphorus and hyperphosphate phosphorus is such as could have been expected. A large part of dicalcium phosphate got into the fluoride-soluble fraction as was previously found (10). It is of interest to note that only 80 per cent of the phosphorus in the sample of basic slag was extracted under the present conditions. In the ratio of 1 to 50 , this percentage was even lower, only about 72 . Since the citric acid solubility of this fertilizer is high (about 98 per cent of the total phosphorus was dissolved by the common method), it is likely that some kind of complex-formation is needed before all the phosphorus in the tetracalcium phosphate, silicocarnotite, and nagelschmidtite of the basic slag may be brought into solution. The distribution of the phosphorus in the Finnish preparates points to the presence of higher phosphates of calcium, or of apatite like compounds.

\section{Incubation experiment}

A simple experiment was carried out in which samples of the four soils were incubated for 24 weeks at room temperature without any treatment or with an application of the five fertilizers, respectively. The following amounts of the fertilizers were applied to 200 g-samples of the soils:

$\begin{array}{ll}\text { Superphosphate } & 1.25 \mathrm{~g} \\ \mathrm{CaHPO}_{4} \cdot 2 \mathrm{H}_{2} \mathrm{O} & 0.55 \mathrm{~g} \\ \text { Hyperphosphate } & 0.75 \mathrm{~g} \\ \text { Basic slag } & 1.25 \mathrm{~g} \\ \text { "Finnish phosphate" } & 1.50 \mathrm{~g}\end{array}$


At the end of the experiment the samples were air-dried at room temperature and ground. The fractions of the inorganic phosphorus were determined in the samples, and the differences in the amounts of phosphorus of the same fraction in the respective fertilized and unfertilized samples were taken to indicate the fertilizer phosphorus in that fraction. The total amount of fertilizer phosphorus recovered and the distribution of this phosphorus into the various fractions are reported in Table 3 .

The $\mathrm{pH}$-values for the soil samples incubated without fertilizers were the following:

\section{$\begin{array}{llll}\text { C } 7: 5.7 & \text { C } 3: 4.2 & \text { Vi } 3: 4.3 & \text { Vi } 1: 3.6\end{array}$}

Table 3. Fertilizer phosphorus in the fractions of inorganic phosphorus in soil samples incubated for 24 weeks

\begin{tabular}{|c|c|c|c|c|c|c|c|}
\hline \multirow{2}{*}{$\begin{array}{l}\text { Fertilizer } \\
\text { P applied }\end{array}$} & \multirow{2}{*}{ Soil } & \multirow{2}{*}{$\begin{array}{c}\text { Final } \\
\mathrm{pH}\end{array}$} & \multirow{2}{*}{$\begin{array}{c}\text { Fertilizer } \\
\text { P ppm } \\
\text { recovered }\end{array}$} & \multicolumn{4}{|c|}{ Per cent of fertilizer-P extracted by } \\
\hline & & & & $\mathrm{NH}_{4} \mathrm{Cl}$ & $\mathrm{NH}_{4} \mathrm{~F}$ & $\mathrm{NaOH}$ & $\mathrm{H}_{2} \mathrm{SO}_{4}$ \\
\hline Superphosphate & C 7 & 5.5 & 500 & 8 & 50 & 38 & 4 \\
\hline \multirow[t]{3}{*}{$550 \mathrm{ppm}$} & C 3 & 4.2 & 540 & 5 & 68 & 26 & 1 \\
\hline & Vi 3 & 4.4 & 560 & 0 & 16 & 78 & 6 \\
\hline & Vi 1 & 3.6 & 530 & 1 & 25 & 71 & 3 \\
\hline \multirow{4}{*}{$\begin{array}{c}\mathrm{CaHPO}_{4} \cdot 2 \mathrm{H}_{2} \mathrm{O} \\
490 \mathrm{ppm}\end{array}$} & C 7 & 5.8 & 470 & 12 & 46 & 36 & 6 \\
\hline & C 3 & 4.4 & 490 & 5 & 71 & 22 & 2 \\
\hline & Vi 3 & 4.6 & 470 & 0 & 18 & 75 & 7 \\
\hline & Vi 1 & 3.7 & 510 & 1 & 26 & 70 & 3 \\
\hline \multirow{4}{*}{$\begin{array}{c}\text { Hyperphosphate } \\
480 \mathrm{ppm}\end{array}$} & C 7 & 7.0 & 450 & 4 & 10 & 3 & 83 \\
\hline & C 3 & 5.7 & 470 & 5 & 41 & 13 & 41 \\
\hline & Vi 3 & 5.4 & 550 & 0 & 6 & 33 & 61 \\
\hline & Vi 1 & 4.5 & 520 & 1 & 24 & 60 & 15 \\
\hline \multirow{4}{*}{$\begin{array}{c}\text { Basic slag } \\
380 \text { ppm }\end{array}$} & C 7 & 6.6 & 390 & 13 & 39 & 19 & 29 \\
\hline & C 3 & 5.2 & 380 & 3 & 70 & 20 & 7 \\
\hline & Vi 3 & 5.1 & 420 & 1 & 15 & 61 & 23 \\
\hline & Vi 1 & 4.1 & 390 & 0 & 27 & 64 & 9 \\
\hline \multirow{4}{*}{$\begin{array}{c}\text { Finnish phosphate } \\
570 \text { ppm }\end{array}$} & C 7 & 5.7 & 570 & 31 & 36 & 12 & 21 \\
\hline & C 3 & 4.5 & 570 & 6 & 64 & 14 & 16 \\
\hline & Vi 3 & 4.6 & 570 & 0 & 19 & 64 & 17 \\
\hline & Vi I & 3.8 & 590 & 1 & 35 & 51 & 13 \\
\hline
\end{tabular}

These values show the typical increase in the acidity, owing to the nitrification and other processes during the incubation. In the $\mathrm{pH}$-values of the samples incubated with a fertilizer, the liming effect of basic slag and particularly that of hyperphosphate are distinct. The other fertilizers have not significantly affected the acidity.

In some cases the amounts of fertilizer phosphorus recovered differ to a certain degree from the corresponding amounts applied. This, probably, arises from the fact that in spite of the most careful mixing of the fertilizers with the soil at the start of the experiment, the distribution could not be made quite homogeneous. 
A higher wrecovery" could, of course, be explained on the basis of a more intensive mineralization of organic phosphorus in the fertilized sample as compared with that in the unfertilized one, or on the basis of a similar difference in the mobilization of the less soluble parts of the inorganic phosphates. The writer thinks, however, that an explanation of this kind is not necessary, and that even a lower recovery may be accounted to the heterogeneity in the distribution of the fertilizer.

It is of interest to note that basic slag has been in all the soils completely recovered.

There seems to be almost no difference in the distributions of superphosphate and dicalcium phosphate phosphorus in the same soils. The proportion of easily soluble phosphorus is low in all the other soils except in the slightly acid C 7 . The largest part of fertilizer phosphorus in this soil is found in the fluoride-soluble fraction and also the alkali-soluble fraction contains a marked amount of fertilizer phosphorus. In the fairly acid silt soil $\mathrm{C} 3$, the accumulation of superphosphate and dicalcium phosphate phosphorus is particularly high in the fluoride-soluble fraction. In the Litorina soils the main part of the fertilizer phosphorus is in the alkali-soluble fraction. Only small amounts are found in the acid-soluble fraction in all the soils.

The hyperphosphate phosphorus, on the other hand, has remained in the acidsoluble form in the sample $\mathrm{C} 7$ the final $\mathrm{pH}$ of which is as high as $\mathrm{pH}$ 7.0. But also in the sample Vi 3 with an acidity of $\mathrm{pH} 5.4$, about 60 per cent of the hyperphosphate phosphorus is found in this fraction. In the sample $\mathrm{Vi} 1$ where the $\mathrm{pH}$ is only 4.5 , in spite of the liming effect of the hyperphosphate, the main part of the fertilizer phosphorus is accumulated in the alkali-soluble fraction, and only 15 per cent is left in the acid-soluble fraction. In the sample C 3 , equal parts of hyperphosphate phosphorus is found in the ammonium fluoride-soluble and in the acid-soluble fractions.

By far the largest part of the phosphorus in basic slag is in the sample C 3 accumulated in the fluoride-soluble fraction, and also in the sample C 7 this fraction contains the highest amount of basic slag phosphorus, although in this sample the distribution of the fertilizer phosphorus has been more even. In the sample C 7 with a final $\mathrm{pH}$ of 6.6 , and in the more acid sample Vi 3 with the $\mathrm{pH} 5.1$, marked amounts of basic slag phosphorus remains in the acid soluble fraction. In the Litorina clays $\mathrm{Vi} 3$ and $\mathrm{Vi} 1$ phosphorus in basic slag is principally converted to the alkali-soluble forms. The fairly high amount of easily soluble fertilizer phosphorus in the sample C 7 is noteworthy.

In this sample the easily soluble fraction of "Finnish phosphaten is surprisingly high, almost equal to the fluoride soluble fraction, or about one third of the total amount. In the other soils the phosphorus of this fertilizer preparate is mainly found in the fluoride-soluble or alkali-soluble fractions, and only rather low amounts remain in the acid soluble forms.

Thus, it seems that in the sample C 3 phosphorus of all the fertilizers studied mainly accumulates as the fluoride-soluble forms. In the Litorina clays the alkalisoluble fraction is the largest in all the cases except in the sample Vi 3 treated with hyperphosphate where the part of the fertilizer phosphorus remaining as the acid- 
Table 4. Distribution of fertilizer phosphorus in fractions of inorganic phosphorus during the fractionation procedure

\begin{tabular}{|c|c|c|c|c|c|c|}
\hline \multirow{2}{*}{$\begin{array}{l}\text { Fertilizer } \\
\text { P applied }\end{array}$} & \multirow{2}{*}{ Soil } & \multirow{2}{*}{$\begin{array}{c}\text { Fertilizer-P } \\
\text { recovered } \\
\text { ppm } \\
\end{array}$} & \multicolumn{4}{|c|}{ Per cent of fertilizer-P extracted by } \\
\hline & & & $\mathrm{NH}_{4} \mathrm{Cl}$ & $\mathrm{NH}_{4} \mathrm{~F}$ & $\mathrm{NaOH}$ & $\mathrm{H}_{2} \mathrm{SO}_{4}$ \\
\hline Superphosfate & C 7 & 550 & 64 & 26 & 9 & 1 \\
\hline \multirow[t]{3}{*}{$550 \mathrm{ppm}$} & C 3 & 550 & 61 & 28 & 10 & 1 \\
\hline & Vi 3 & 540 & 15 & 20 & 62 & 3 \\
\hline & Vi 1 & 550 & 24 & 25 & 48 & 3 \\
\hline $\mathrm{CaHPO}_{4} \cdot 2 \mathrm{H}_{2} \mathrm{O}$ & C 7 & 480 & 44 & 34 & 7 & 15 \\
\hline \multirow[t]{3}{*}{$490 \mathrm{ppm}$} & C 3 & 500 & 45 & 46 & 9 & 0 \\
\hline & Vi 3 & 440 & 9 & 24 & 63 & 4 \\
\hline & Vi 1 & 480 & 11 & 27 & 56 & 6 \\
\hline Hyperphosphate & C 7 & 470 & 3 & 3 & 2 & 92 \\
\hline \multirow[t]{3}{*}{$480 \mathrm{ppm}$} & C 3 & 410 & 9 & 11 & 10 & 70 \\
\hline & Vi 3 & 410 & 1 & 5 & 26 & 68 \\
\hline & Vi 1 & 450 & 5 & 13 & 31 & 51 \\
\hline Basic slag & C 7 & 320 & 18 & 26 & 13 & 43 \\
\hline \multirow[t]{3}{*}{$380 \mathrm{ppm}$} & C 3 & 350 & 11 & 42 & 8 & 39 \\
\hline & Vi 3 & 230 & 3 & 16 & 55 & 26 \\
\hline & $\mathrm{Vi} 1$ & 250 & 2 & 18 & 42 & 38 \\
\hline "Finnish phosphater & C 7 & 560 & 40 & 31 & 6 & 23 \\
\hline \multirow[t]{3}{*}{$570 \mathrm{ppm}$} & C 3 & 500 & 25 & 51 & 11 & 13 \\
\hline & Vi 3 & 500 & 5 & 22 & 56 & 17 \\
\hline & Vi 1 & 440 & 2 & 28 & 45 & 25 \\
\hline
\end{tabular}

soluble forms is surprisingly high when an acid soil is in question. Attention may be paid to the fairly high quantities of fertilizer phosphorus in the easily soluble fraction in the sample C 7. This sample, usually, contains somewhat more phosphorus in the acid-soluble fraction than do the distinctly acid soils.

\section{Fractionation without incubation}

It is a matter of course that during the fractionation procedure the fertilizer phosphorus will react with the soil constituents, and that the ions of the extractants may to a considerable degree influence these reactions. In order to find out to what extent the forms of the fertilizer phosphorus may be changed during the analysis, a series of fractionations was carried out using the same soils and the same fertilizers as in the incubation experiment.

The $1 \mathrm{~g}$-samples of the soils were weighed to the centrifuge tubes, and the fertilizers were added as $5 \mathrm{ml}$-portions of their water suspension prepared immediately before the application. In spite of the most careful manipulation, no very high accuracy was attained, and there was variation in the amounts of fertilizer phosphorus recovered in replicate fractionations. The results reported in Table 4 are average values of four replicate analyses. The writer thinks that there is not 
evidence enough to suppose that the recovery of the fertilizer phosphorus would have been incomplete, except perhaps in the cases of basic slag in the samples of Vi 3 and Vi 1, and "Finnish phosphate" in the sample Vi 1.

The superphosphate phosphorus has reacted with the slightly acid sample C 7 in a way almost similar to that in the distinctly acid sample C 3 : about one third of the easily soluble phosphorus has been converted to forms extractable mainly by ammonium fluoride, and, to a lesser degree, first by sodium hydroxide. In the sample Vi 3 which is particularly rich in iron, the largest part of the fertilizer phosphorus is found in the alkali-soluble fraction. About one half of the fertilizer phosphorus in the sample $\mathrm{Vi} 1$ is in this fraction. The ammonium fluoride fraction contains in all the soils about one fourth of the fertilizer phosphorus.

Almost one half of the dicalcium phosphate phosphorus is in the easily soluble fraction in samples C 7 and C 3 , but its content in the fluoride-soluble fraction is also high, particularly in the sample C 3 . In the Litorina soils the fertilizer phosphorus is mainly accumulated in the alkali-soluble fraction, with about one fourth of it in the fluoride-soluble forms.

The reactions of the hyperphosphate phosphorus with the soil $\mathrm{C} 7$ seem to be slight during the fractionation. In the samples $\mathrm{C} 3$ and $\mathrm{Vi} 3$, the dissolution of the apatite phosphorus is more marked, but first in the very acid soil, Vi 1, almost one half of this phosphorus is extracted by the non-acid solutions.

In the sample C 7 the largest part of the phosphorus of basic slag is found in the acid-soluble fraction, while in the sample C 3 the fluoride-soluble fraction is as high as this latter one. A not insignificant part of the fertilizer phosphorus is in the easily soluble form in both these soils. It seems that the recovery of the basic slag phosphorus in the acid soils Vi 3 and Vi 1, rich in sesquioxides, has been rather poor. The largest parts of the phosphorus extracted was found in the alkalisoluble and acid-soluble fractions.

Relatively small parts of the "Finnish phosphate" phosphorus are left in the acid-soluble fraction in all the samples. In the Litorina soils the highest amounts are accumulated in the alkali-soluble fraction while in the sample C 3 the fluoridesoluble fraction is the richest in fertilizer phosphorus, and in the sample $C$, the main part of the fertilizer phosphorus could be extracted with ammonium chloride.

Thus, it appears that particularly in the acid soils which are rich in iron and aluminium, the main part of the water-soluble phosphorus of superphosphate, of the less soluble phosphorus in dicalcium phosphate, and even of the mostly acidsoluble compounds of basic slag and "Finnish phosphaten may be converted to the alkali-soluble forms during the fractionation procedure. In the presence of the slightly acid soil the changes in the distribution of the fertilizer phosphorus into the various fractions are not less marked, although often different. The same holds true with the acid silt soil C 3 in the presence of which the fertilizer phosphorus tends to accumulate particularly in the fluoride-soluble fraction.

\section{Discussion}

The fractionation procedure used in the present work is supposed to differentiate soil inorganic phosphorus into forms associated with aluminium, iron, and 
calcium. There are, however, some doubts concerning the accuracy of this method. Particularly two possible errors have been emphasized: some aluminium-bound phosphorus may be adsorbed by ferric oxide, and some iron-bound phosphorus may get into the acid-soluble fraction, owing to the incomplete dissolution of it by the alkali treatment (1). Then there is the question of the changes in the forms of soil phosphorus during the extraction procedure which may be quite essential when freshly applied phosphorus compounds are included. It is also unknown to what extent the presence of a fairly high amount of a fertilizer will change the solubility of the native soil phosphorus. This means that the difference between the phosphorus contents of a certain fraction in the fertilized and unfertilized soils may not give a quite reliable picture of the content of fertilizer phosphorus in this fraction. Therefore, the results of the present experiments must be interpreted with caution.

The results of the fractionation of the fertilizers are not comparable with those obtained when fertilizers in soil samples were analyzed. This it not only because of the presence of the soil, but also because the ratio of fertilizer to solution was 1 to 100 when the mere fertilizers were analyzed, and about 100 times lower when the fertilizers were fractionated in the soil samples. It is likely that the changes in the forms of phosphorus during the fractionation of the incubated samples were smaller than those in the samples to which the fertilizers were applied immediately before the analysis.

During the fractionation of the unincubated samples, a relatively high portion of the water-insoluble fertilizer phosphorus and the monocalcium phosphate of the superphosphate reacted with the soil constituents. In the samples of the acid soils Vi 3 and Vi 1, rich in iron and aluminium, the main part of this phosphorus is found in the fraction of iron-bound forms, and a markedly lower portion in the aluminiumbound fraction. In the acid silt soil C 3 , the dissolved fertilizer phosphorus tends to become aluminum-bound, but a part of the phosphorus of dicalcium phosphate and "Finnish phosphaten is also found as the easily soluble forms. In most cases, the portion of easily soluble phosphorus in the slightly acid sandy clay C 7 is surprisingly high.

The very low capacity of this slightly acid soil to sorb phosphate explains why even in the incubated samples a fairly high proportion of the large application of the fertilizer phosphorus may occur as the easily soluble forms. The main part of the fertilizer phosphorus is, however, bound by aluminium. The only exception is hyperphosphate phosphorus the mobilization of which seems to be markedly lowered by the neutralizing effect of this fertilizer.

The acid silt soil C 3 has not a much higher content of acid-oxalate soluble aluminium than has the slightly acid sandy clay. Yet, by far the largest part of the fertilizer phosphorus is in this soil bound by aluminium, even a marked portion of the hyperphosphate phosphorus. Phosphorus in the ammonium fluoride soluble fraction is considered to be fairly easily available to plants. MacKEnzIE (13) found that this fraction usually supplies most of the water-soluble phosphorus in soil suspensions, and according to Hanley (8), aluminium-bound phosphorus is the 
preferred source of phosphorus to various crops. Thus, it may be supposed that in this soil the availability of all these fertilizers will be fairly high.

The accumulation of the fertilizer phosphorus in the iron-bound fraction in the two acid Litorina soils is increased by the incubation. There is some tendency towards higher amounts of fertilizer phosphorus in the aluminium bound forms in the sample $\mathrm{Vi} 1$ than in the sample Vi 3, corresponding to the differences in the contents of iron and aluminium in these samples. In the sample $\mathrm{Vi} 3$, there is a relatively high amount of acid-soluble fertilizer phosphorus both in the sample treated with hyperphosphate and in the sample treated with basic slag. In the almost equally acid silt sample C 3 , these both fertilizers have been dissolved fairly effectively and their phosphorus distributed into other fractions. It may be mentioned that a second extraction with sodium hydroxide did not increase the content of iron-bound phosphorus in the samples of Vi 3: therefore, it is not likely, that any significant amounts of iron-bound fertilizer phosphorus would have been left in the acid-soluble fraction in this soil. Perhaps the result, after all, has something to do with the high iron content of this soil. There is some evidence that soils which respond well to rock phosphate are those which are acid and with a low content of iron (4). This is a problem which needs further research.

The equal distribution of superphosphate phosphorus and dicalcium phosphate phosphorus in the respective incubated soils is in accordance with the observations (9) that monocalcium phosphate rapidly turns over into dicalcium phosphate in the soil. The slow mobilization of hyperphosphate phosphorus, except in the very acid soil, is also demonstrated by the present results. The compounds in basic slag, on the other hand, seem to be mobilized more rapidly even in the less acid soils although in some cases their recovery from a fresh application seemed to be poor. The results concerning the "Finnish phosphate" indicate that this preparate could be a valuable phosphorus fertilizer in different kinds of our soils.

\section{$S u m m$ ary}

In the present work an attempt was made to follow in laboratory experiments the distribution of fertilizer phosphorus into the various fractions of soil inorganic phosphorus using the procedure of CHANG and JAckson (3). Four mineral soils were selected for these studies. Their acidity varied from $\mathrm{pH} 3.7$ to $\mathrm{pH} 6.0$ (in $0.02 \mathrm{~N} \mathrm{CaCl}_{2}$ ), clay content from 28 to 54 per cent, and the indicator of their capacity to sorb phosphate from 135 to 1000 . The fertilizers studied were superphosphate, $\mathrm{CaHPO}_{4} \cdot 2 \mathrm{H}_{2} \mathrm{O}$ (chemical grade), hyperphosphate, basic slag, and a preparate of fused apatite called in this work the "Finnish phosphaten.

In the soil samples incubated with an application of fertilizers corresponding to about $500 \mathrm{ppm} \mathrm{P}$ for 24 weeks at room temperature, the fertilizer phosphorus accumulated in various fractions mainly according to the properties of the soils. In the two acid Litorina soils rich in sesquioxides and with a high capacity to sorb phosphate, the main part of the fertilizer phosphorus was found in the alkali-soluble fraction in most the cases, with a not insignificant amount in the fluoride-soluble fraction. The only exceptions occurred in the distribution of hyperphosphate phos- 
phorus, and to a lesser degree, of phosphorus in basic slag, in the sample particularly rich in iron where a large portion of fertilizer phosphorus remained in the acidsoluble forms. In the slightly acid sandy clay the distribution of the fertilizer phosphorus into the different fractions was more uniform than in the other soils, only the hyperphosphate phosphorus largely remained in the acid-soluble forms. In the acid silt soil with a typical average capacity to sorb phosphate, the main part of the fertilizer phosphorus was in all cases found in the fluoride-soluble fraction.

The equal distribution of superphosphate phosphorus and dicalcium phosphate phosphorus in the respective incubated soils is in accordance with the claim that monocalcium phosphate rapidly turns over into dicalcium phosphate in the soil. The well known slow mobilization of hyperphosphate phosphorus in all but the very acid soils is also demonstrated by the present results, but the slow reaction of this fertilizer in the acid soil with a very high content of iron may be worth of further studies. The compounds of basic slag seem to be mobilized fairly rapidly even in the less acid soils. The results concerning the "Finnish phosphaten indicate that this preparate may be a valuable phosphorus fertilizer in various kinds of our soils.

During the fractionation procedure the reactions of the fertilizer phosphorus compounds with the soil constituents seem to be marked, the trend and the rate of the reactions largely depending on the properties of the soils.

\section{REFERENCES}

(1) Aung, K. \& Leeper, G. W. 1960. Modifications in Chang and Jackson's procedure for fractionating soil phosphorus. Agrochimica 4: 246-254.

(2) Chang, S. C. \& ChU, W. K. 1961. The fate of soluble phosphate applied to soils, J. Soil. Sci. 12: $286-293$.

(3) Chang, S. C. \& Jackson, M. L. 1957. Fractionation of soil phosphorus. Soil Sci. 84: 133-144.

(4) Снu, C. R. \& Moschler, W. W. \& Tномas, G. W. 1962. Rock phosphate transformations in acid soils. Soil Sci. Soc. Amer. Proc. 26: 476-478.

(5) Ellis, R. Jr. \& Quader, M. A. \& Truog, E. 1955. Rock phosphate availability as influenced by soil $\mathrm{pH}$. Ibid. 19: 484-487.

(6) FIFE, C. V. 1959. An evaluation of ammonium fluoride as a selective extractant for aluminium bound soil phosphate: II. Soil Sci. 87: 83-88.

(7) Fine, L. O. \& Bartholomew, R. P. 1947. The fates of rock and superphosphate applied to a red podzolic soil. Soil Sci. Soc. Amer. Proc. 11: 195-197.

(8) Hanley, K. 1962. Soil phosphorus forms and their availability to plants. Irish J. Agric. Res. 1: $192-193$.

(9) Huffman, E. O. 1962. Reactions of phosphate in soils: recent research by TVA. Fertilizer Society Proc. 71.

(10) Kalla, A. 1961. Fertilizer phosphorus in some Finnish soils. J. Sci. Agr. Soc. Finland 33: 131-139.

(11) - - 1961. Effect of incubation and liming on the phosphorus fractions in soil. Ibid. 33: 185193.

(12) $-\rightarrow$ 1963. Organic phosphorus in Finnish soils. Soil Sci. 95: 38-44.

(13) MacKenzie, A. F. 1962. Inorganic soil phosphorus fractions of some Ontario soils as studied using isotopic exchange and solubility criteria. Canad. J. Soil Sci. 42: 150-156.

(14) Rathje, W. 1961. Zur Möglichkeit der Düngung mit Rohphosphat. Plant and Soil XIV: $82-84$.

(15) Schoen, U. \& Barbier, G. \& HÉnin, S. 1954. Sur l'evolution des phosphates calciques dans les conditions du sol. Ann. agron. Paris 5: 441-457. 
(16) UlRICH, B. 1959. Theoretische Betrachtungen zur Frage der Rohphosphat-Wirkung. Landw, Forsch. 12: $30-36$.

(17) Wright, B. C. \& PeEch, M. 1960. Characterization of phosphate reaction products in acid soils by the application of solubility criteria. Soil Sci. 90: $32-43$.

SELOST U S :

\title{
LANNOITEFOSFORIN SIJOITTUMISESTA MAAN EPÄORGAANISEN FOSFORIN FRAKTIOIHIN
}

\author{
Armi Kaila \\ Yliopiston maanviljelyskemian laitos, Helsinki
}

Tutkimuksessa on yritetty selvittää superfosfaatin, dikalsiumfosfaatin, hienofosfaatin, thomasfosfaatin ja Lohjan Kalkkitehdas Oy:n lannoitepreparaatin fosforin jakautumista eri fraktioihin neljällä maalla suoritetuissa laboratoriokokeissa.

Todettiin, että 24 viikon muhituskokeen aikana lannoitefosforin kertyminen eri fraktioihin riippui lähinnä maan ominaisuuksista. Happamissa ja runsaasti seskvioksideja sisältåvissä Litorina-savissa suurin osa lannoitefosforista oli emäkseen liukenevassa fraktiossa, jonkin verran myös fluoridiin liukenevassa. Poikkeuksena oli erittäin raudanpitoinen näyte, jossa hienofosfaatin ja pienemmåssä määrässä myös thomasfosfaatin fosfori näytti jäăvăn happoon liukenevaan fraktioon. Heikosti happamassa hietasavessa lannoitefosfori näytti jakaantuvan suhteellisesti tasaisemmin kaikkien fraktioiden kesken kuin muissa näytteissä, kuitenkin suurin osa lannoitefosforista oli kertynyt fluoridiin liukenevaan fraktioon. Happamassa hiesussa, jonka fosforin pidätyskyky oli keskinkertainen, ehdottomasti suurin osa lannoitefosforista kertyi fluoridiin liukenevaan muotoon.

Superfosfaatin ja dikalsiumfosfaatin fosforin samanlainen jakaantuminen samoissa maanäytteissă vahvistaa havaintoja, joiden mukaan monokalsiumfosfaatti muuttuu maassa nopeasti dikalsiumfosfaatiksi. Hienofosfaatin hidas mobilisoituminen muissa paitsi erittäin happamissa maissa kuvastuu myös tämän tutkimuksen tuloksista, jotka kuitenkin antavat aihetta kiinnittää huomiota hienofosfaatin käyttökelpoisuuden huononemiseen runsaasti rautaa sisältävissä maissa. Thomasfosfaatin vaikeasti liukeneva fosfori näytti mobilisoituvan melko hyvin lievästikin happamissa maissa. Lohjan Kalkkitehdas Oy:n lannoitepreparaatti näyttää näiden laboratoriotutkimusten perusteella varsin tehokkaalta fosforilannoitteelta erilaisissa maissamme.

Työssä kiinnitettiin myös huomiota lannoitefosforin reaktioihin maan ainesosien kanssa jo fraktioinnin aikana ja todettiin, että hyvinkin suuria muutoksia saattaa tapahtua. 